\title{
TUNNEKUVAUSTEN SUKUPUOLIEROT AUTISMIKIRJON JA VERROKKIRYHMÄN NUORTEN AIKUISTEN KERRONNASSA
}

Katja Dindar, Logopedian tutkimusyksikkö, Oulun yliopisto Soile Loukusa, Logopedian tutkimusyksikkö, Oulun yliopisto Leena Mäkinen, Logopedian tutkimusyksikkö, Oulun yliopisto Aija Kotila, Logopedian tutkimusyksikkö, Oulun yliopisto Tuula Hurtig, Neurotieteen tutkimusyksikkö, PEDEGOtutkimusyksikkö, Oulun yliopisto ja Lastenpsykiatrian vastuualue, Oulun yliopistollinen sairaala

Hanna Ebeling, PEDEGO-tutkimusyksikkö, Lääketieteellinen tiedekunta, Oulun yliopisto ja Lastenpsykiatrian vastuualue, Oulun yliopistollinen sairaala

\begin{abstract}
Aiemmissa tutkimuksissa on saatu ristiriitaisia tuloksia autismikirjon naisten ja miesten tavasta orientoitua sosiaalisiin tilanteisiin, tulkita niitä ja kertoa niistä. Tässä tutkimuksessa tarkastelimme, kuinka autismikirjon naiset $(n=7)$ ja miehet $(n=24)$ ja verrokkiryhmän naiset $(n=11)$ ja miehet $(n=24)$ kuvaavat sosiopragmaattisesti monimutkaisissa videoleikkeissä esiintyvien henkilöiden tunteita. Tarkastelimme tutkittavien vapaata kerrontaa keskittyen siihen, kuinka paljon tutkittavat tuottivat suoria ja epäsuoria tunnekuvauksia sekä missä määrin he taustoittivat tunnekuvauksiaan. Tutkimuksessa havaittiin verrokkiryhmän naisten ja autismikirjon naisten tuottavan enemmän epäsuoria tunnekuvauksia kuin autismikirjon miesten. Lisäksi autismikirjon miesten, mutta ei naisten, havaittiin taustoittavan tunnekuvauksiaan vähemmän kuin verrokkiryhmän naisten ja verrokkiryhmän miesten. Verrokkiryhmän naiset ja verrokkiryhmän miehet eivät eronneet toisistaan suorien tai epäsuorien tunnekuvausten määrässä tai tunnekuvausten taustoittamisessa. Tulokset kannustavat kiinnittämään huomiota sukupuolierojen tarkasteluun, jotta autismikirjon naisia ja autismikirjon miehiä voidaan sekä tunnistaa paremmin että tukea kohdennetummin.
\end{abstract}

Avainsanat: autismikirjo, kerronta, sukupuoli, tunnekuvaukset, tunteet

Kirjoittajan yhteystiedot:

Katja Dindar

katja.dindar@oulu.fi 


\section{JOHDANTO}

Autismikirjon henkilöt eroavat neurotyypillisistä henkilöistä sosioemotionaalisessa vuorovaikutuksessa ja kommunikaatiossa (American Psychiatric Association, 2013; World Health Organization, 2018). Eroja on havaittu muun muassa siinä, kuinka sosiaalisiin tilanteisiin orientoidutaan ja miten näitä tilanteita tulkitaan (Avni ym., 2019; Loukusa, painossa; Loukusa \& Moilanen, 2009; Loukusa, Mäkinen, Kuusikko-Gauffin, Ebeling \& Leinonen, 2018; Lönnqvist ym., 2017). Sosiaalisten tilanteiden tulkintaan vaikuttaa esimerkiksi kyky tunnistaa ja tulkita toisten henkilöiden tunteita. Toisten tunteiden tunnistamisen ja nimeämisen onkin havaittu olevan haasteellista autismikirjon henkilöille (esim. Bal ym., 2010; Eack, Mazefsky \& Minshew, 2015; Kuusikko ym., 2009), joskaan eroja autismikirjon ja neurotyypillisten henkilöiden välillä ei ole havaittu kaikissa tutkimuksissa (Tracy, Robins, Schriber \& Solomon, 2011). Eackin ym. (2015) tutkimuksen mukaan autismikirjon aikuisten virhetulkinnat liittyvät esimerkiksi iloisten ja surullisten kasvonilmeiden tulkitsemiseen neutraaleina ja neutraaleiden vihaisina. Tällaiset virhetulkinnat voivat tehdä sosiaalisesta vuorovaikutuksesta monin tavoin haastavaa ja työlästä sekä autismikirjon henkilöille että heidän vuorovaikutuskumppaneilleen.

Tunteiden tunnistamisen lisäksi voidaan autismikirjon henkilöiden kerrontaa tarkastelemalla tutkia, millaisia tunnekuvauksia he tuottavat. Avoimet tehtävät, joissa pyydetään esimerkiksi vapaasti kuvailemaan nähtyä videoleikettä, antavat tietoa tutkittavien spontaanista tavasta jäsentää näkemäänsä sekä siitä, mitä tutkittavat pitävät erityisen tärkeänä kertoa (esim. Barnes, Lombardo, Wheelwright \& Baron-Cohen, 2009; Boorse ym., 2019; Klin, 2000). Keskittymällä siihen, kuinka usein kerronnassa viitataan muiden henkilöiden tunteisiin ja mielentiloihin, on pyritty arvioimaan sitä, missä määrin tällainen tunteiden ja mielentilojen tarkastelu on tutkittaville tärkeää ja toisaalta missä määrin he siinä onnistuvat. Tätä on pidetty autismikirjon tutkimuksessa olennaisena autismikirjoon liitettyjen sosioemotionaalisten haasteiden vuoksi. Näihin katsotaan kuuluvaksi muun muassa vaikeus hahmottaa, mitä muut henkilöt ajattelevat ja tuntevat sekä miksi näin tapahtuu (Baron-Cohen \& Wheelwright, 2004). Kysymys on tärkeä myös sosiaalisen motivaation näkökulmasta. Neurotyypillisiä henkilöitä vähäisempää sosiaalista motivaatiota on pidetty eräänä autismikirjon henkilöiden sosiaalisen vuorovaikutuksen ja kommunikaation haasteita selittävänä tekijänä (Chevallier, Kohls, Troiani, Brodkin \& Schultz, 2012). Toisaalta viimeaikainen tutkimus on korostanut sosiaalisen motivaation tilannekohtaisuutta ja osoittanut muun muassa, että autismikirjon henkilöt voivat olla halukkaampia vuorovaikutukseen muiden autismikirjon henkilöiden kuin neurotyypillisten henkilöiden kanssa (Morrison ym., 2019).

Haasteet kerronnassa voivat osaltaan vaikeuttaa vuorovaikutussuhteita, koska kerronta on keskeisessä roolissa ihmisten jokapäiväisessä elämässä. Autismikirjon henkilöiden kerronnassa voi näkyä haasteet arvioida, mitä vastaanottaja mahdollisesti jo tietää ennalta, ja siten päättää, kuinka paljon ja millaista informaatiota on tarpeen tarjota (Volden, Magill-Evans, Goulden \& Clarke, 2007). Tällaisen taustoittamisen tarpeen huomioimisen eli pragmaattisesti taitavan kommunikoinnin onkin havaittu olevan haasteellista autismikirjon lapsille ja aikuisille (Loukusa, painossa; Loukusa ym., 2018; Loukusa \& Moilanen, 2009; Mäkinen ym., 2014). Autismikirjon henkilöiden on todettu tuottavan vähemmän muun muassa koherenttia kerrontaa (Baixauli, Colomer, Roselló \& Miranda, 2016; Losh \& Gordon, 2014) ja toisaalta käyttävän enemmän epäselviä pronomineja (Colle, Baron- 
Cohen, Wheelwright \& van der Lely, 2008; Norbury, Gemmell \& Paul, 2014), mikä voi vaikeuttaa kuulijan mahdollisuuksia ymmärtää kertojaa ja tämän kerronnan sisältöä.

Mielentilojen ja tunnekuvausten tuottamista tarkasteleva kerronnan tutkimus on keskittynyt pitkälti lapsiin. Autismikirjon lasten on muun muassa havaittu kuvaavan vähemmän muiden mielentiloja (Kauschke, van der Beek \& Kamp-Becker, 2016) ja tunteita (Siller, Swanson, Serlin \& Teachworth, 2014) kuin neurotyypillisten lasten, joskaan näitä eroja ei ole löydetty kaikissa tutkimuksissa (esim. Capps, Losh \& Thurber, 2000; Mäkinen ym., 2014). Myös aikuisia koskevissa tutkimuksissa on saatu paikoin ristiriitaisia tuloksia verrattaessa autismikirjon ja neurotyypillisten henkilöiden kerrontaa ja erityisesti sitä, missä määrin he keskittyvät toisten tunteiden ja mielentilojen kuvaukseen. Esimerkiksi Barnes ym. (2009) havaitsivat neurotyypillisten aikuisten tuottavan enemmän kuvauksia mielentiloista ja tunteista kuin autismikirjon aikuisten, kun taas joissakin toisissa tutkimuksissa vastaavaa eroa ei ole löydetty (FletcherWatson, Leekam \& Findlay, 2013; Freeth, Ropar, Mitchell, Chapman \& Loher, 2011). Kuvausten määrän lisäksi on tutkittu eroja, joita esiintyy tunteille ja mielentiloille annetuissa selityksissä ja niiden taustoituksessa eli missä määrin kuvataan esimerkiksi tunnetilaa kokevaa henkilöä ja tunnetilan syytä (esim. tuo lapsi on iloinen, koska hän sai jäätelön). Tutkimuksissa on havaittu autismikirjon lasten tuottavan vähemmän selityksiä muiden mielentiloille (Capps ym., 2000). Aikuisten osalta tutkimus on keskittynyt laajemmin kerronnassa tuotettujen tapahtumien selityksiin ja taustoittamiseen, jota autismikirjon aikuisten on raportoitu tekevän neurotyypillisiä aikuisia vähemmän (esim. Barnes \& Baron-Cohen, 2012).
Kerronnassa näyttää olevan sukupuolieroja $^{1}$. Neurotyypillisten tyttöjen ja naisten kerronnan on todettu olevan muun muassa tunnesävytteisempää ja käsittelevän enemmän henkilöiden mielentiloja kuin neurotyypillisten poikien ja miesten (Buckner \& Fivush, 1998; Niedźwieńska, 2003; Schulkind, Schoppel \& Scheiderer, 2012). Vastaavasti autismikirjon tyttöjen on havaittu tuottavan autismikirjon poikia enemmän toisten henkilöiden mielentilojen kuvauksia (Boorse ym., 2019; Kauschke ym., 2016). Toisaalta sekä autismikirjon tyttöjen että autismikirjon poikien on raportoitu tuottavan neurotyypillisiä tyttöjä vähemmän tunnekuvauksia (Kauschke ym., 2016). Kuitenkin Conlon ym. (2019) havaitsivat, että autismikirjon tytöt tuottavat enemmän henkilöiden aikomusten kuvauksia kuin autismikirjon pojat, mutta mielentilojen tai tunteiden kuvauksissa sukupuolieroja ei löytynyt. Tarkastellessaan mielentilojen taustoitusta, Kauschke ym. (2016) havaitsivat sekä neurotyypillisten tyttöjen että autismikirjon tyttöjen taustoittavan mielentilojen kuvauksiaan autismikirjon poikia enemmän. Autismikirjon tyttöjen ja neurotyypillisten tyttöjen välillä ei ollut eroa. Tutkimusalueen kokonaiskuva on kuitenkin vielä epäselvä ja autismikirjon aikuisia koskevan tutkimuksen tarve ilmeinen.

Sukupuolieroja autismikirjon henkilöiden kerronnassa on pyritty selittämään muun muassa sosiaalisen naamioitumisen käsitteellä (engl. camouflage). Tällä viitataan siihen, että erityisesti autismikirjon tyttöjen ja naisten on havaittu opettelevan ja käyttävän strategioita, joiden avulla selviytyä erilaisissa sosiaalisissa tilanteissa ja ikään kuin naamioida haasteensa (Dean, Harwood \& Kasari,

\footnotetext{
${ }^{1}$ Sukupuolierojen tutkimuksessa voidaan viitata toisaalta fysiologisten ja hormonaalisten tekijöiden perusteella määriteltävään biologiseen sukupuoleen, toisaalta henkilön yksilölliseen sukupuoli-identiteettiin. Tässä artikkelissa viittaamme sukupuoli-sanalla ensisijaisesti syntymässä määriteltyyn biologiseen sukupuoleen.
} 
2017; Lai ym., 2011). Tutkimuksissa on havaittu autismikirjon tyttöjen olevan autismikirjon poikia taitavampia muun muassa ymmärtämään erilaisten kielellisten keinojen sosiaalisia merkityksiä ja käyttävän näitä keinoja eri tavoin vuorovaikutuksessa (Parish-Morris ym., 2017). Aiemmat tutkimukset kuitenkin viittaavat siihen, että autismikirjon tytöt ja naiset onnistuvat naamioitumisessa joillakin alueilla, kun taas joillakin toisilla alueilla heidän haasteensa ovat hyvin samankaltaisia kuin autismikirjon pojilla ja miehillä (esim. Boorse ym., 2019; Lai ym., 2011; Lai, Lombardo, Auyeung, Chakrabarti \& BaronCohen, 2015). Tutkimuksissa on esimerkiksi havaittu autismikirjon naisilla olevan autismikirjon miehiä vähemmän sosiaalisen kommunikaation haasteita (Lai ym., 2011), mutta toisaalta autismikirjon naisilla ja autismikirjon miehillä on raportoitu samanlaisia haasteita toisten henkilöiden mielentilojen ja tunteiden tunnistamisessa (Lai ym., 2015). Kerronnan tarkastelu voi täydentää näitä havaintoja antamalla tietoa siitä, kuinka paljon autismikirjon naiset ja miehet tuottavat toisten henkilöiden mielentilojen ja tunteiden kuvauksia vapaassa kerronnassaan, ja siten auttaa arvioimaan sitä, missä määrin tunneja mielentilojen tarkastelu on heille tärkeää.

Menetelmällisesti kiinnostava havainto on, että useissa aiemmissa kerrontatutkimuksissa on tarkasteltu tutkittavien tuottamia mielentilojen (esim. ajatella) ja tunteiden (esim. iloita) kuvauksia yhdessä, tekemättä eroa näiden välille (esim. Fletcher-Watson ym., 2013). Aiempien tutkimusten tulokset ovat kuitenkin vaihdelleet sen mukaan, onko autismikirjon ja neurotyypillisten henkilöiden tai sukupuolten välillä löydetty eroja mielentilojen kuvauksissa vai tunnekuvauksissa (esim. Boorse ym., 2019; Conlon ym., 2019; Kauschke ym., 2016; Siller ym., 2014). Aiemmat ristiriitaiset tutkimustulokset voivatkin liittyä siihen, kuinka aineistoja on luokiteltu tutkimuksissa varsin eri tavoin. Tunteisiin keskittyneissä tutkimuksissa tunteiden sisältöä on toisinaan pyritty luokittelemaan tarkemmin. Tyypillistä on muun muassa jako perustunteisiin (esim. ilo, suru) ja monimutkaisiin tunteisiin, joiden ajatellaan edellyttävän henkilöiden uskomusten tai aikomusten ymmärtämistä (esim. itsevarmuus, kiinnostuneisuus; Baron-Cohen, Wheelwright, Hill, Raste \& Plumb, 2001). Vähemmän huomiota sen sijaan on kiinnitetty laadullisesti siihen tapaan, jolla tunnekuvauksia tuotetaan.

Tunteiden sisällön tarkastelun sijasta voidaankin tutkia tunnekuvausten tuottamisen tapaa. Tässä tutkimuksessa tarkastelemme sitä, kuinka tunnekuvauksia voidaan hahmottaa sen perusteella, kuinka suoria ja julkilausuttuja (engl. explicit) tai toisaalta epäsuoria ja julkilausumattomia (engl. implicit) ne ovat. Autismikirjon tutkimus on keskittynyt erityisesti suorien tunnekuvausten tarkasteluun, jollaisia ovat esimerkiksi kirjallisuudessa kuvatut perustunteet (esim. mies on surullinen) ja monimutkaiset tunteet (esim. nainen on pettynyt; Baron-Cohen ym., 2001). Vähemmän huomiota on kiinnitetty muunlaiseen tunnepitoiseen kerrontaan, jota voidaan käyttää muun muassa henkilöiden tunteiden kuvaamiseen (esim. mies ei pysty käsittelemään niin vaikeaa asiaa) tai yleisempään tunnelman luonnehdintaan (esim. odottava tunnelma). Tällaisia kuvauksia tarkastelemme epäsuorina tunnekuvauksina. Neurotyypillisten henkilöiden kerrontaa tarkastelevissa tutkimuksissa osaa tällaisista epäsuorista tunnekuvauksista on tarkasteltu tunnesävyttyneenä kerrontana (esim. tunnesävyttyneen toiminnan kuvaus lapsi itkee; Buckner \& Fivush, 1998). Autismikirjon tutkimuksissa taas tunnesävyttynyttä toimintaa on voitu luokitella esimerkiksi ihmisiin liittyväksi ei-sosiaaliseksi informaatioksi sillä perusteella, että tunnesävyttyneen toiminnan kuvausten voidaan ajatella vaativan 
vähemmän tulkintaa kuin suorien tunnekuvausten (Fletcher-Watson ym., 2013). Epäsuorat tunnekuvaukset ovat siten pääasiassa jääneet vähälle huomiolle autismikirjon tutkimuksessa. Epäsuorien tunnekuvausten tarkastelu kuitenkin tuottaa tietoa siitä, missä märin autismikirjon naiset ja miehet ylipäätänsä tuottavat tunnesävyttynyttä kerrontaa vastapainona suorien tunnekuvausten tarkastelulle, joka keskittyy henkilöiden varsinaisiin tunteisiin viittaavien sanojen käyttämiseen. Siten epäsuorien tunnekuvausten tarkastelu auttaa ymmärtämään, missä märin tunnesävyttynyttä sisältöä ylipäätänsä pidetään niin tärkeänä, että sitä tuotetaan vapaassa kerronnassa.

Tässä tutkimuksessa tarkastelemme, onko autismikirjon naisten ja miesten sekä verrokkiryhmän naisten ja miesten välillä eroa tunnekuvausten tuottamisen tavassa. Tutkimuskysymyksemme ovat seuraavat:

1. Eroavatko ryhmät toisistaan suorien tunnekuvasten määrässä?

2. Eroavatko ryhmät toisistaan epäsuorien tunnekuvasten määrässä?

3. Eroavatko ryhmät toisistaan tunnekuvausten taustoittamisen määrässä?

\section{AINEISTO JA MENETELMÄT}

\subsection{Tutkittavat}

Tähän tutkimukseen osallistui 32 autismikirjon (miehiä 25 , naisia 7 ) ja 35 verrokkiryhmän (miehiä 24, naisia 11) nuorta aikuista. Tutkittavat ovat alun perin osallistuneet $\mathrm{Ou}-$ lun yliopistollisen sairaalan lastenpsykiatrian klinikan kliiniseen autismikirjon tutkimukseen (Kuusikko ym., 2008; Weiss ym., 2009) tai epidemiologiseen tutkimukseen Pohjois-
Pohjanmaan sairaanhoitopiirin alueella (Mattila ym., 2007) vuosina 2000-2003. Tuolloin autismikirjon häiriön diagnoosit asetettiin ICD-10-tautiluokituksen kriteerien (World Health Organization, 1993) mukaan Autism Diagnostic Interview Revised (ADI-R; Lord, Rutter \& Le Couteur, 1995) ja Autism Diagnostic Observation Schedule (ADOS; Lord, Rutter, DiLavore \& Risi, 2000) -menetelmiin sekä muuhun kliiniseen informaatioon nojautuen. Verrokkiryhmän tutkittavat valittiin epidemiologisen tutkimuksen osallistujista (Mattila ym., 2007), satunnaisesti (Kuusikko ym., 2008; Kuusikko ym., 2009) tai rekrytoitiin Oulun alueen kouluista (Jansson-Verkasalo ym., 2005). Tutkimukselle oli Pohjois-Pohjanmaan sairaanhoitopiirin eettisen toimikunnan puoltava lausunto.

Yhdellä autismikirjon miehellä esiintyi huomattava määrä toistavaa puhetta, minkä vuoksi tutkittavan aineistoa ei sisällytetty tähän tutkimukseen, jotta määrällinen tarkastelu ei vääristyisi. Tässä tutkimuksessa analysoitiin aineistoa siis kaikkiaan 31:ltä autismikirjon nuorelta aikuiselta sekä 35 verrokkiryhmän nuorelta aikuiselta. Tiedot tutkittavien iästä ja sukupuolesta perustuivat rekisteritietoihin. Tutkittavien ikä -muuttuja ei ollut normaalisti jakautunut, joten autismikirjon naisten ja miesten sekä verrokkiryhmän naisten ja miesten välisen eron tarkastelussa käytettiin nonparametrista Kruskal-Wallisin testiä. Tilastollisesti merkitsevää eroa ei havaittu $\left(\chi^{2}=2,977, p=0,395\right)$ neljän tutkittavan ryhmän iän välillä (ks. taulukko 1 ). 
TAULUKKO 1. Tutkittavien iän, kielellisen ymmärtämisen ja yleisen kykyindeksin keskiarvot, mediaanit ja keskihajonnat.

\begin{tabular}{|c|c|c|c|c|c|c|c|c|c|}
\hline & \multicolumn{3}{|l|}{ ikä } & \multicolumn{3}{|c|}{$\begin{array}{l}\text { kielellinen } \\
\text { ymmärtäminen }\end{array}$} & \multicolumn{3}{|c|}{$\begin{array}{l}\text { yleinen } \\
\text { kykyindeksi }\end{array}$} \\
\hline & ka & $M d$ & $k h$ & ka & $M d$ & $k h$ & ka & $M d$ & $k h$ \\
\hline $\begin{array}{l}\text { Autismikirjon } \\
\text { naiset }\end{array}$ & 23,6 & 22,5 & 3,5 & 108,4 & 104,0 & 15,7 & 104,9 & 102,0 & 13,2 \\
\hline $\begin{array}{l}\text { Autismikirjon } \\
\text { miehet }\end{array}$ & 23,4 & 23,0 & 2,6 & 109,4 & 111,0 & 19,1 & 110,5 & 110,5 & 17,4 \\
\hline $\begin{array}{l}\text { Verrokkiryhmän } \\
\text { naiset }\end{array}$ & 21,3 & 22,3 & 1,4 & 107,1 & 108,0 & 11,4 & 103,1 & 102,0 & 12,7 \\
\hline $\begin{array}{l}\text { Verrokkiryhmän } \\
\text { miehet }\end{array}$ & 23,1 & 22,6 & 1,9 & 107,3 & 112,0 & 14,1 & 106,3 & 108,0 & 11,2 \\
\hline
\end{tabular}

Tutkittavien kognitiivinen suoriutuminen ja kielellinen ymmärtäminen olivat keskitasoa Wechsler Adult Intelligence Scale - IV -arviointimenetelmällä tarkasteltuna (Wechsler, 2012). Yleisen kykyindeksin ja kielellisen suoriutumisen muuttujat olivat normaalisti jakautuneita, joten ryhmien välisten erojen tarkastelussa käytettiin yksisuuntaista varianssianalyysiä. Autismikirjon naiset ja miehet sekä verrokkiryhmän naiset ja miehet eivät eronneet toisistaan tilastollisesti merkitsevästi yleisen kykyindeksin $(F(3,62)=0,836$, $p=0,479)$ tai kielellisen ymmärtämisen $(F(3,62)=0,059, p=0,981)$ perusteella.

\subsection{Menetelmät}

Tutkittaville näytettiin osana laajempaa koeasetelmaa videoleikkeitä suomalaisesta, vuosina 1990-1991 MTV-televisiokanavalla esitetystä kokoperheen tv-sarjasta Ruusun aika. Videoleikkeiden näyttämisessä noudatettiin MTV-televisiokanavalta saatua ohjeistusta. Tutkittavia pyydettiin katsomaan seitsemän lyhyttä videoleikettä yksitellen ja kunkin leikkeen jälkeen kertomaan vapaasti, mitä leikkeessä tapahtui. Tavoitteena oli tutkittavien mahdollisimman itsenäisesti tuottamat kuvaukset, joten tutkijat eivät esittäneet tutkittaville tarkentavia kysymyksiä ja pitäytyivät kommentoimasta tutkittavien vastauksia.

Videoleikkeisiin oli valittu sosiopragmaattisesti haastavia vuorovaikutustilanteita, joissa ilmeni usein ristiriitoja tv-sarjan henkilöiden välillä. Leikkeissä korostui esimerkiksi henkilöiden tunnetilojen tulkitseminen voimakkaasti tunnelatautuneissa vuorovaikutustilanteissa sekä henkilöiden mielentilojen tulkitseminen hienovaraisten sosiopragmaattisten vihjeiden perusteella. Esimerkiksi eräs leike keskittyi kahden nuoren naisen väliseen keskusteluun, jossa toinen kertoi kärsivänsä siitä, että ihmiset kiinnittävät häneen ja hänen erikoisuuteensa huomiota. Naisen kerronnassa oli monenlaisia sävyjä, muun muassa kehuskelua. Kertojan sanat ja kehonkieli olivat keskenään ristiriidassa ja leikkeen tulkinnan voidaan ajatella edellyttävän hienojakoista tilannekohtaista tulkintaa.

Tutkittavien kerronta litteroitiin äänitallenteilta tekstimuotoon ja luokiteltiin luokittelurungon avulla. Luokittelurunko rakennettiin aiemman tutkimuksen ja aineiston pohjalta. Se on pyynnöstä saatavilla kirjoittajilta. 


\subsection{Munttujat}

Aineistoa tarkasteltiin ensin laadullisesti eri tavoin tuotettujen tunnekuvausten ja niiden taustoittamisen tunnistamiseksi. Tähän tarkasteluun ja aiempaan tutkimukseen nojaten muodostettiin luokittelurunko.

Suorat ja epäsuorat tunnekuvaukset. Aineistosta tunnistettiin suoria ja epäsuoria tunnekuvauksia. Suoriksi tunnekuvauksiksi katsottiin aiempiin tutkimuksiin nojaten selkeät toisen henkilön tunnetilan kuvaukset (esim. Baron-Cohen ym., 2001). Tässä tutkimuksessa emme erotelleet toisistaan perustunteiden ja monimutkaisten tunteiden kuvauksia, vaan luokittelimme ne kaikki suoriksi tunnekuvauksiksi perustuen niiden tuottamisen tapaan. Aineistosta havaittiin myös muunlaisia tunnekuvauksia, joita kutsutaan tässä tutkimuksessa epäsuoriksi tunnekuvauksiksi. Tutkimuksessamme tällaiset epäsuorat tunnekuvaukset kuvasivat joko yleistä tunnelmaa (esim. ahdistava tunnelma) tai tunnesävyttynyttä toimintaa (esim. he riitelivät), toivat tunnetilan näkyväksi lainaamalla tai keksimällä henkilölle vuorosanoja (esim. tämä vaaleatukkanen tyttö että joo että soronnoo), tai kuvasivat henkilöjen orientaatiota toistensa tunnetiloihin (esim. oli vähän silleen katteli että mitä on tekeillä). Tässä tutkimuksessa emme arvottaneet, olivatko tunnekuvaukset "onnistuneita" tai kuvasivatko ne osuvasti sitä videoleikettä, joihin ne oli tuotettu. Tilastollista analyysia varten laskimme kaikki suorat ja epäsuorat tunnekuvaukset. Analyysiyksikkönä oli yksittäinen sana (esim. masentunut) tai ajatuskokonaisuus (esim. mies sai kierrellen ja kaarrellen kerrottua). Emme suhteuttaneet tuotettuja tunnekuvauksia kerronnan pituuteen (esim. sanamäärään), koska tarkastelimme tunnekuvauksia omassa kerronnan kontekstissaan ensisijaisesti suhteessa siihen videoleikkeeseen, johon ne oli tuotettu. Seuraavat aineistonäytteet havainnollistavat luokittelua.
Aineistonäyte 1: aika järkyttyny (suora tunnekuvaus, verrokkiryhmän henkilö):

täämiesoli aikajärkyttynyja sittesen vaimo tuli kotia ja se kerto sille että jollaki Sennillä on syöpä oiskohan se niitten tyttö esimerkiks

Aineistonäyte 2: vähä niinku tolaltaan (suora tunnekuvaus, autismikirjon henkilö):

joo se mies tulee taloonsa on vähä niinku tolaltaan ja istuutuu alas ja vaimo saapuu ja ku ne puhuu $r$-ra-selvillä että jollakulla on syöpä

Aineistonäyte 3: vähän vaikeemmasta asiasta ja ei halua käsitellä (epäsuorat tunnekuvaukset, verrokkiryhmän henkilö):

no tämä oli vissiin tämä ukko oli oli lääkäri itse ehkä tämmösellä lääkärikielellä puhu pubu tämmösestä vähän vaikeemmasta asiasta että ei halua käsitellä niin suoraan

Aineistonäyte 4: valittaa valittamasta päästyä̈n (epäsuora tunnekuvaus, autismikirjon henkilö):

\section{jaa nuorempi muija valittaa valittamasta päästyään ja siinä kai seo}

Tunnekuvausten taustoittaminen. Perustuen muun muassa Kauschken ym. (2016) aiempaan tutkimukseen tarkastelimme myös, kuinka paljon tutkittavat taustoittivat tunnekuvauksiaan. Analyysimme keskittyi erityisesti siihen, kuvasivatko tutkittavat, kenen tunteesta oli kysymys ja mistä tunne johtui. Sekä henkilön että tunteen syyn mainintaa edellytettiin. Tunnekuvausten taustoituksessa tarkastelimme ainoastaan suoria tunnekuvauksia, koska epäsuorien tunnekuvausten kohdalla esimerkiksi tietyn henkilön mainitseminen ei useimmiten ollut relevanttia (esim. kun kuvailtiin yleistä tunnelmaa). Analyysissä käytettiin hyväksi kaikkea kerrontaa, jonka 
tutkittava kyseiseen videoleikkeeseen tuotti. Tunnekuvausten taustoitusta tarkasteltiin prosentuaalisesti laskemalla, kuinka suuri osa tutkittavien suorista tunnekuvauksista oli taustoittamattomia.

Aineistonäyte 5: kovastiabistaa (taustoitettu tunnekuvaus, tunteen syy ja tunnetta kokeva henkilö on mainittu, verrokkiryhmän henkilö):

no joo että tota Heidiä kovasti abistaa se ku joutuu aina olemaan huomion keskipisteenä

Aineistonäyte 6: ottaa pattiin (taustoittamaton tunnekuvaus, tunteen syy on mainittu, tunnetta kokevaa henkilöä ei ole mainittu, autismikirjon henkilö):

mmm ilimeisesti jollaki on syöpä ja se ottaa pattiin

\subsection{Luokittelun luotettavuustarkastelu}

Luokittelun luotettavuutta tarkasteltiin luokittelemalla noin $14 \%$ aineistosta uudelleen siten, että luotettavuustarkastelussa olivat mukana kaikki tutkittavat ja kaikki videoleikkeet. Luokittelun luotettavuustarkastelun suoritti itsenäisesti logopedian maisterivaiheen opiskelija. Opiskelijalla ei ollut käytettävissään tietoa tutkittavien diagnooseista tai sukupuolesta. Opiskelijan luokittelua verrattiin ensimmäisen kirjoittajan suorittamaan luokitteluun. Luotettavuutta tarkasteltiin sisäkorrelaation avulla (intra-class correlation coefficient, ICC(2), two-way random, single measure, absolute agreement). Luokittelijoiden välinen luotettavuus oli kohtalainen tunnekuvausten taustoittamisen $(0,59)$ ja suorien tunnekuvausten $(0,73)$ mutta erinomainen epäsuorien tunnekuvausten $(0,91)$ osalta (ks. Koo \& Li, 2016).

\subsection{Tilastolliset menetelmät}

Tilastollisissa analyyseissä käytettiin nonparametrisia menetelmiä, koska tarkasteltavat muuttujat eivät olleet normaalisti jakautuneita. Lisäksi naisten ryhmien koot olivat pienet ja vertailtavat ryhmät erisuuruiset. Eroja autismikirjon naisten ja miesten sekä verrokkiryhmän naisten ja miesten välillä tarkasteltiin Kruskal-Wallisin testillä. Post hoc -vertailuissa käytettiin Dunnin monivertailutestiä. Kaikki raportoidut $p$-arvot on korjattu Bonferroni-menetelmällä kertomalla alkuperäiset $p$-arvot tehtyjen vertailujen lukumäärällä. Kruskal-Wallisin testin efektikokoa on arvioitu $\varepsilon^{2}$ (Tomczak \& Tomczak, 2014). Aineiston analyysissa hyödynnettiin IBM SPSS Statistics 25 -ohjelmistoa.

\section{TULOKSET}

\subsection{Suorat tunnekuvaukset}

Suorien tunnekuvausten tuottamista tarkasteltiin ensin Kruskal-Wallisin testillä. Testi osoitti tilastollisesti merkitsevän eron neljän vertaillun ryhmän (autismikirjon naiset, autismikirjon miehet, verrokkiryhmän naiset, verrokkiryhmän miehet) välillä $\left(\chi^{2}=7,855\right.$, $\left.p=0,049, \varepsilon^{2}=0,121\right)$. Parittaiset vertailut Dunnin monivertailutestillä osoittivat kuitenkin, että erot ryhmien välillä eivät olleet tilastollisesti merkitseviä, kun p-arvot korjattiin Bonferroni-menetelmällä kertomalla alkuperäinen p-arvo tehtyjen vertailujen lukumäärällä. Ryhmien välillä tehtyjen vertailujen p-arvot vaihtelivat välillä 0,097-1,000 (ks. kuvio 1). 


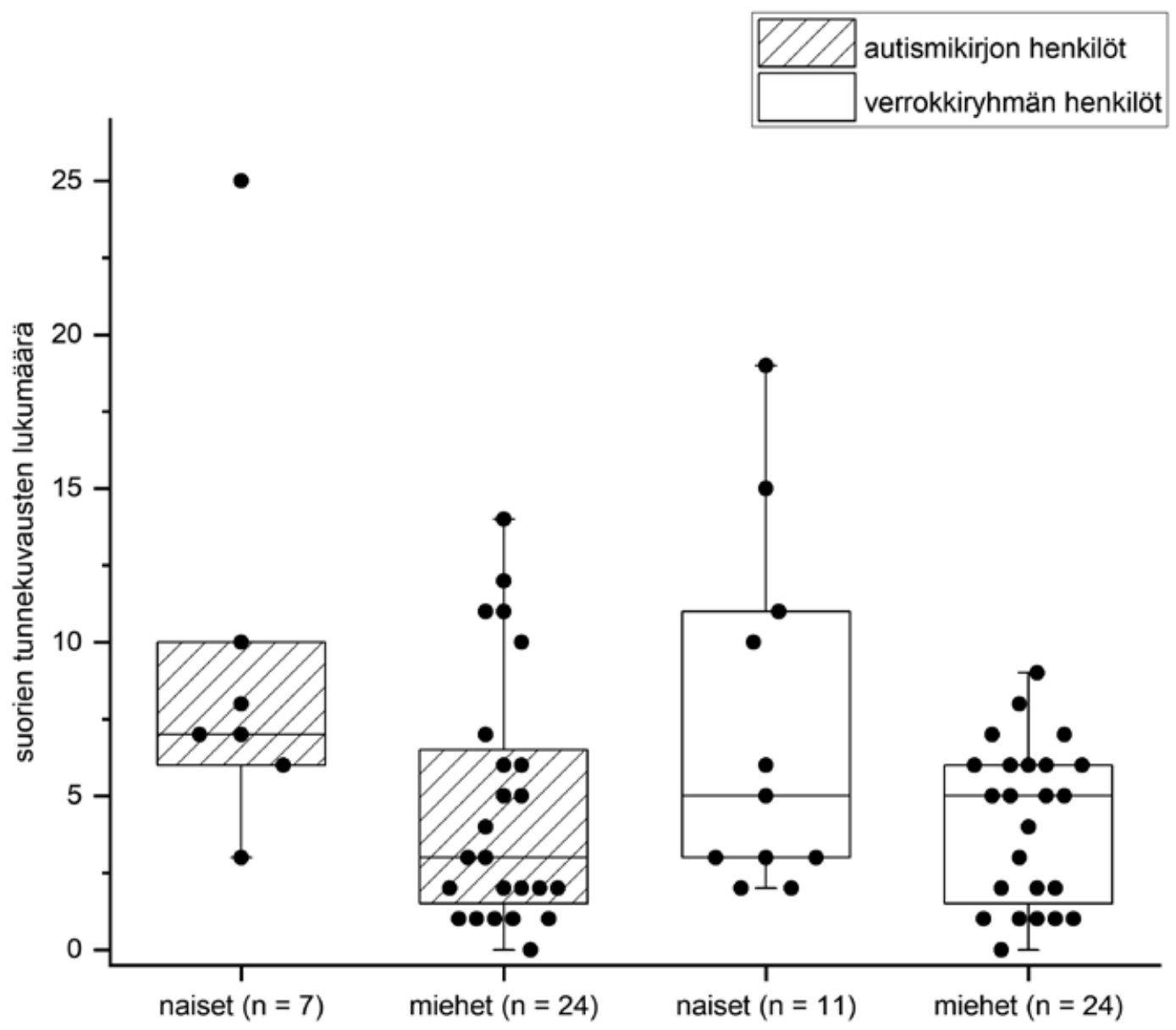

KUVIO 1. Suorat tunnekuvaukset autismikirjon naisten, autismikirjon miesten, verrokkiryh. män naisten ja verrokkiryhmän miesten kerronnassa. Kuviossa keskilukuna mediaani. Ympyräsymbolit kuvaavat yksittäisiä tutkittavia.

\subsection{Epäsuorat tunnekuvaukset}

Vastaavasti epäsuorien tunnekuvausten tuottamista tarkasteltiin ensin Kruskal-Wallisin testillä. Testi osoitti tilastollisesti merkitsevän eron neljän vertaillun ryhmän välillä $\left(\chi^{2}=11,458, p=0,009, \varepsilon^{2}=0,176\right)$. Dunnin monivertailutestin Bonferroni-korjattujen tulosten mukaan autismikirjon miehet tuot- tivat vähemmän epäsuoria tunnekuvauksia kuin autismikirjon naiset $(p=0,037)$ ja verrokkiryhmän naiset $(p=0,049)$. Muut neljän ryhmän välillä tehdyt vertailut eivät olleet tilastollisesti merkitseviä ( $p$-arvot vaihtelivat välillä 0,542-1,000, ks. kuvio 2). 


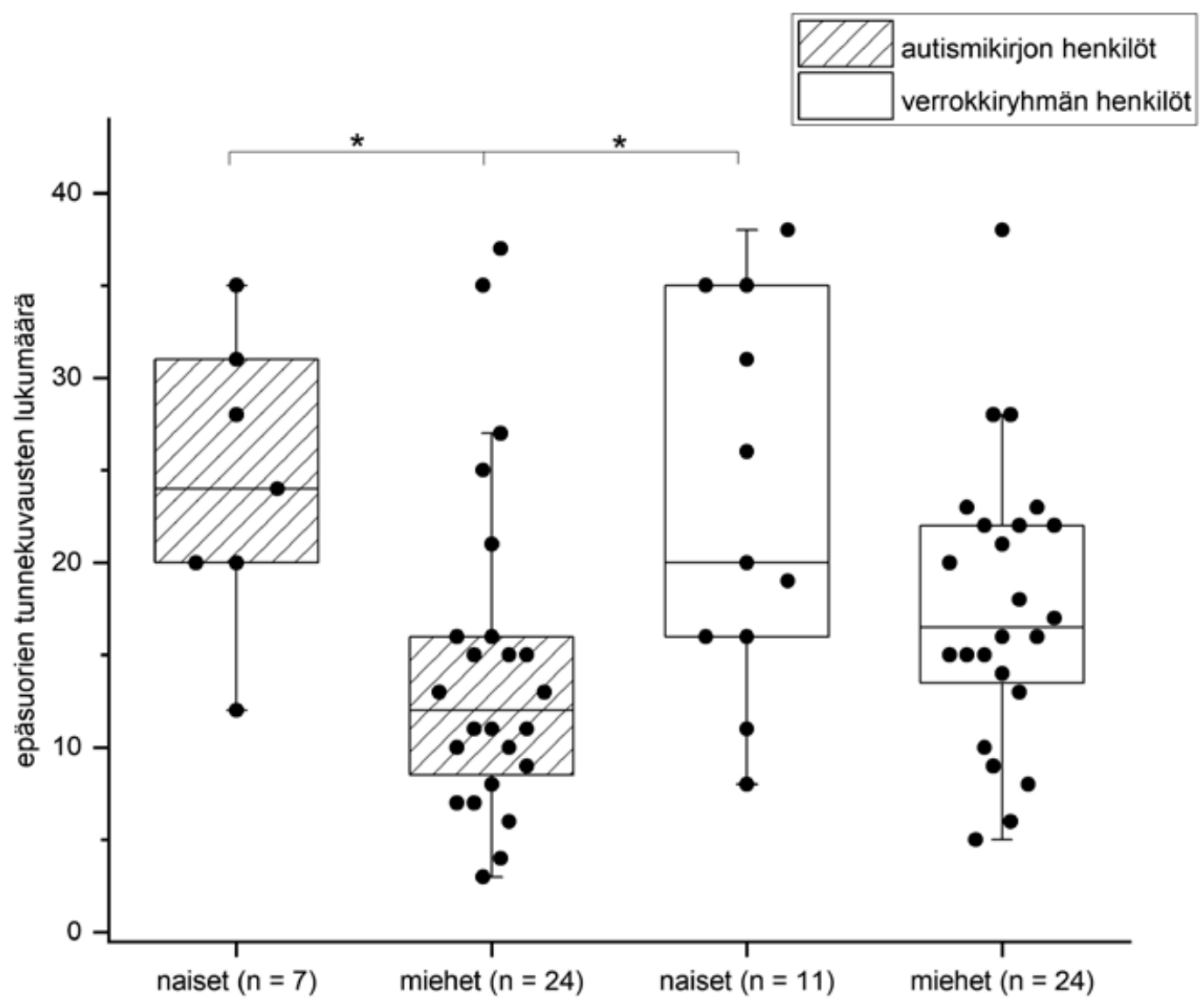

KUVIO 2. Epäsuorat tunnekuvaukset autismikirjon naisten, autismikirjon miesten, verrokkiryhmän naisten ja verrokkiryhmän miesten kerronnassa. Kuviossa keskilukuna mediaani. Ympyräsymbolit kuvaavat yksittäisiä tutkittavia. ${ }^{*} p<0,05$.

\subsection{Tunnekuvausten taustoittaminen}

Tunnekuvausten taustoittamisen määrää tarkasteltiin ensin Kruskal-Wallisin testillä. Testi osoitti tilastollisesti merkitsevän eron neljän vertaillun ryhmän välillä $\left(\chi^{2}=28,480, p<\right.$ $\left.0,001, \varepsilon^{2}=0,452\right)$. Dunnin monivertailutestin Bonferroni-korjattujen tulosten mukaan autismikirjon miehet tuottivat enemmän taustoittamattomia tunnekuvauksia kuin verrokkiryhmän naiset $(p=0,001)$ ja verrok- kiryhmän miehet $(p<0,001)$. Autismikirjon miehistä 17/23 tuotti taustoittamattomia tunnekuvauksia, kun verrokkiryhmän naisten ryhmässä osuus oli $1 / 11$ ja verrokkiryhmän miesten ryhmässä 1/23 (ks. kuvio 3). Muut neljän ryhmän välillä tehdyt vertailut eivät olleet tilastollisesti merkitseviä ( $p$-arvot vaihtelivat välillä 0,073-1,000). 


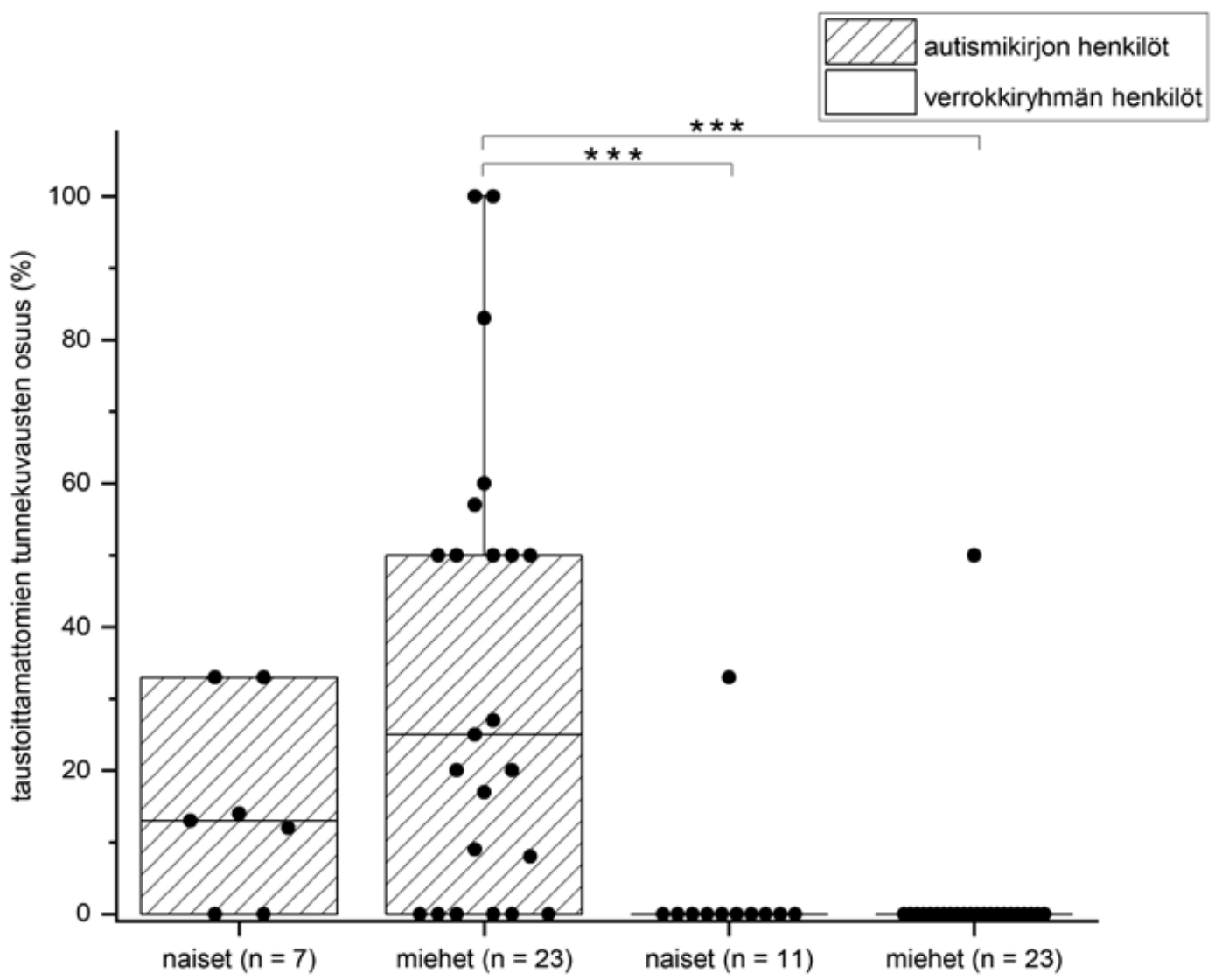

KUVIO 3. Taustoittamattomien tunnekuvausten osuus (\%) autismikirjon naisten, autismikirjon miesten, verrokkiryhmän naisten ja verrokkiryhmän miesten kerronnassa. Kuviossa keskilukuna mediaani. Ympyräsymbolit kuvaavat yksittäisiä tutkittavia. Autismikirjon miesten $n=23$ ja verrokkiryhmän miesten $n=23$, koska kaksi autismikirjon miestä ja yksi verrokkiryhmän mies eivät tuottaneet lainkaan suoria tunnekuvauksia, joiden taustoittamista tarkasteltiin. ${ }^{* *} p \leq 0,001$.

\section{POHDINTA}

Tässä tutkimuksessa tarkastelimme autismikirjon naisten ja miesten sekä verrokkiryhmän naisten ja miesten tunnekuvausten tuottamisen tapaa. Tarkastelun kohteena oli, missä määrin henkilöt tuottivat suoria ja epäsuoria tunnekuvauksia sosiopragmaattisesti haastavien videoleikkeiden pohjalta. Lisäksi olimme kiinnostuneita siitä, minkä verran he taustoittivat tunnekuvauksiaan eli mainitsi- vatko he, kenen tunteesta oli kysymys ja mistä tunne mahdollisesti johtui.

Emme havainneet tutkittujen ryhmien välillä tilastollisesti merkitseviä eroja suorien tunnekuvausten määrässä. Autismikirjon ja verrokkiryhmän naisia oli tutkimuksessamme suhteellisen vähän, mikä on voinut vaikuttaa siihen, ettei tilastollisesti merkitseviä eroja havaittu. Autismikirjon ja verrokkiryhmän nais- 
ten ja miesten välisten erojen puuttuminen tukee kuitenkin niitä aiempia tutkimuksia, joissa autismikirjon ja neurotyypillisten henkilöiden välillä ei ole havaittu eroja suorien tunnekuvausten tuottamisessa (Fletcher-Watson ym., 2013; Freeth ym., 2011, ks. kuitenkin Barnes ym., 2009; Siller ym., 2014). Toisaalta tuloksemme verrokkiryhmän naisten ja miesten erojen puuttumisesta poikkeaa aiempien tutkimuksien tuloksista, joissa neurotyypillisten tyttöjen ja naisten on havaittu tuottavan enemmän tunnesävyttynyttä kerrontaa kuin neurotyypillisten poikien ja miesten (Buckner \& Fivush, 1998; Niedźwieńska, 2003).

Epäsuorien tunnekuvausten tarkastelu osoitti tilastollisesti merkitseviä eroja ryhmien välillä. Sekä autismikirjon että verrokkiryhmän ryhmän naiset tuottivat enemmän epäsuoria tunnekuvauksia kuin autismikirjon miehet. Sen sijaan autismikirjon miehet eivät eronneet tilastollisesti merkitsevästi verrokkiryhmän miehistä eivätkä verrokkiryhmän miehet kummastakaan naisryhmästä. Tuloksemme tukee osittain Kauschken ym. (2016) tutkimuksen tulosta, jossa havaittiin neurotyypillisten tyttöjen tuottavan enemmän tunnekuvauksia kuin autismikirjon tytöt ja pojat. Samoilla linjoilla on myös Conlonin ym. (2019) tutkimus. Näissä aikaisemmissa tutkimuksissa ei siis tullut esille sitä autismikirjon ryhmän sisäistä sukupuolten välistä eroa, joka näkyy nyt saamissamme tuloksissa. Tuloksemme poikkeavat myös verrokkiryhmän naisten ja miesten osalta aiempien tutkimusten (esim. Buckner \& Fivush, 1998; Niedźwieńska, 2003) tuloksista.

On syytä huomioida se, että tutkimuksemme epäsuorat tunnekuvaukset pitivät sisällään monin tavoin erilaista tunnesävyttynyttä kerrontaa kuin Bucknerin ja Fivushin (1998), Conlonin ym. (2019), Kauschken ym. (2016) ja Niedźwieńskan (2003) tutkimusten tunnekuvaukset, jotka muistuttivat pääasiassa tämän tutkimuksen suoria tunnekuvauksia.
Onkin mahdollista, että tunnekuvausten määritelmiin liittyvät tekijät selittävät näitä tuloksia. Siinä missä aiemmat tutkimukset ovat tunnekuvausten osalta keskittyneet pääosin suorien tunnekuvausten tarkasteluun, tutkimuksessamme huomioimme myös laadullisesti eri tavalla tuotetut epäsuorat tunnekuvaukset. Nimenomaan epäsuorien tunnekuvausten tuottamisen tarkastelu osoitti eroja toisaalta autismikirjon miesten ja naisten ja toisaalta autismikirjon miesten ja verrokkiryhmän naisten välillä. Kuitenkaan eroja verrokkiryhmän naisten ja miesten välillä ei havaittu. Lisätutkimukselle olisi tarvetta näiden aiemmista tutkimuksista osin eriävien tulosten vuoksi. Erityisesti aikuisten kerronnan tarkastelu olisi tärkeä lisä lapsiin keskittyneiden tutkimusten rinnalle.

Tutkimuksemme eräs keskeinen havainto on autismikirjon naisten tuottamien suorien ja epäsuorien tunnekuvausten verrattain suuri määrä (joskin tilastollisesti merkitsevästi autismikirjon naiset erosivat ainoastaan autismikirjon miehistä epäsuorissa tunnekuvauksissa). Ensinnäkin tämä tukee ajatusta sukupuolierojen tarkastelun tärkeydestä autismikirjon tutkimuksessa (esim. Lai ym., 2015). Autismikirjon poikien ja miesten piirteisiin perustuvat luonnehdinnat autismikirjosta voivat osaltaan vaikeuttaa autismikirjon tyttöjen ja naisten tunnistamista ja tukemista (Dean ym., 2017; Lai ym., 2011), mikä on nykyisellään yhä haaste. Toiseksi autismikirjon naisten tuottamien tunnekuvausten suuri määrä voi tukea ajatusta autismikirjon tyttöjen ja naisten sosiaalisesta naamioitumisesta eli siitä, että he käyttävät erilaisia strategioita sopeutuakseen neurotyypillisten henkilöiden joukkoon (Dean ym., 2017). Tässä tapauksessa on mahdollista, että autismikirjon naiset ovat erityisesti pinnistelleet tuottaakseen kerrontaa, jonka ovat tulkinneet olevan tilanteeseen sopivaa. Jatkossa olisi hyvä tarkastella, onko autismikirjon naisten sosiaalisen naami- 
oitumisen harjoittelulla yhteyttä siihen, etteivät autismikirjon tytöt ja pojat näytä eroavan tunnekuvausten tuottamisessa lapsuudessa (Conlon ym., 2019; Kauschke ym., 2016) vaan mahdollisesti vasta aikuisuudessa. Autismikirjon tyttöjen ja naisten mahdollisen naamioitumisen tunnistaminen olisi tärkeää, koska jatkuva yritys sopeutua ja mukauttaa omaa toimintaa voi olla autismikirjon tytöille ja naisille pidemmän päälle kuormittavaa. Sosiaalisen naamioitumisen teorian sijasta voidaan toisaalta ajatella, että autismikirjon naiset olivat yksinkertaisesti autismikirjon miehiä taitavampia epäsuorien tunnekuvausten tuottamisessa.

Tutkimuksessamme havaitsimme eroja myös autismikirjon miesten, verrokkiryhmän naisten ja verrokkiryhmän miesten välillä tunnekuvausten taustoittamisessa eli siinä, missä määrin tutkittavat selittivät syitä tunteille ja mainitsivat, kenen tunteesta oli kysymys. Tulostemme mukaan verrokkiryhmän naiset ja verrokkiryhmän miehet taustoittivat tunnekuvauksiaan enemmän kuin autismikirjon miehet, joiden välillä vaihtelua oli paljon. Tunnekuvausten taustoittamatta jättäminen oli kuitenkin varsin poikkeuksellista verrokkiryhmän henkilöille, mihin suhteutettuna autismikirjon miesten tunnekuvausten taustoittamattomuuden määrä näyttäytyy merkityksellisenä. Siinä missä osa autismikirjon miehistä taustoitti tunnekuvauksiaan paljon, osa ei taustoittanut lainkaan tai taustoitti hyvin vähän, mikä kuvastaa myös sitä variaatiota, jota autismikirjon henkilöiden välillä tiedetään olevan. Tällaisten kerrontaansa vähän taustoittavien yksilöiden tunnistaminen ja tukeminen on käytännössä tärkeää sekä autismikirjon henkilöille itselleen että heidän vuorovaikutuskumppaneilleen. Vähäinen taustoittaminen voi hankaloittaa omien ajatusten välittämistä kuulijoille ja ymmärretyksi tulemista, mikäli kuulijan on vaikeaa hahmottaa, mistä kertoja tarkalleen ottaen puhuu tai mihin hän kerronnassaan viittaa.

Löydös on kiinnostava myös sen vuoksi, että autismikirjon naisten ja autismikirjon miesten välillä ei havaittu eroa tunnekuvausten taustoittamisessa. Toisaalta autismikirjon naiset eivät myöskään eronneet verrokkiryhmän naisista tai verrokkiryhmän miehistä. Siten tuloksemme tukee osittain aiempia tutkimuksia, joissa autismikirjon lasten ja aikuisten on havaittu tuottavan vähemmän taustoitusta henkilöiden mielentiloille ja ylipäätänsä kertomalleen kertomukselle kuin neurotyypillisten lasten ja aikuisten (Barnes \& Baron-Cohen, 2012; Capps ym., 2000). Sukupuolierojen osalta tuloksemme on osittain yhteneväinen Kauschken ym. (2016) havainnon kanssa, jonka mukaan autismikirjon pojat taustoittivat mielentilojen kuvauksiaan vähemmän kuin neurotyypilliset tytöt. Sen sijaan Kauschken ym. tutkimuksessa autismikirjon pojat erosivat myös autismikirjon tytöistä, mitä emme havainneet tutkimuksemme autismikirjon naisten ja autismikirjon miesten välillä. Toisaalta koska tutkimuksemme autismikirjon naiset eivät myöskään eronneet verrokkiryhmän naisista tai verrokkiryhmän miehistä, näyttää mahdolliselta, että nimenomaan autismikirjon pojat ja miehet (eivät tytöt ja naiset), tuottavat tämän muissakin tutkimuksissa havaitun eron mielentilojen ja tunteiden kuvausten taustoittamisessa autismikirjon ja neurotyypillisten henkilöiden välillä. Myös Kauschken ym. (2016) tutkimus tukee tätä päätelmää.

Havaitsemamme tunnekuvausten taustoituksen vähäisyys voi liittyä autismikirjon miesten haasteisiin asettua videolla näkyvien henkilöiden asemaan ja hahmottaa syitä näiden tunnekokemuksille (Baron-Cohen \& Wheelwright, 2004). Erot tunnekuvausten taustoittamisessa voivat liittyä myös pragmaattisiin taitoihin arvioida vastaanottajan näkökulmaa ja sitä, mitä tämä jo tietää, ja siten 
tuottaa riittävä määrä tilannekohtaista tietoa (Volden ym., 2007). Toisaalta tutkimuksemme tutkittavat katsoivat videoleikkeet yhdessä tutkijan kanssa, joten he olivat täysin tietoisia siitä, että myös tutkija näki samat videoleikkeet eikä taustoittaminen siten ollut välittömän ymmärretyksi tulemisen kannalta tarpeellista. Eräs selitys tuloksellemme voi sen sijaan olla se, että verrokkiryhmän henkilöt orientoituivat kerrontatilanteeseen ensisijaisesti institutionaalisena tutkimustilanteena ja tuottivat kerrontaansa erityisen tietoisina siitä, että sitä ja sen rakennetta voidaan arvioida. Tulevaisuudessa kannattaa tarkastella myös luonnollisissa vuorovaikutustilanteissa tuotettua kerrontaa, jotta tilannekohtaisten tekijöiden merkitystä voidaan ymmärtää paremmin.

Sosiaalisen motivaatioteorian (Chevallier ym., 2012) näkökulmasta tuloksiamme voidaan tulkita myös siten, että autismikirjon miehet saattoivat olla vähemmän kiinnostuneita videoleikkeiden tunnepitoisesta sisällöstä - tai paremminkin, muiden ryhmien kerronta oli "vinoutunut" tunnepitoisen sisällön käsittelyyn. On syytä korostaa, että tuloksemme kertoo ensisijaisesti siitä, mitä tutkittavat pitivät kertomisen arvioisina ja mahdollisesti tärkeinä asioina. Vaikka on mahdollista, että autismikirjon miesten tuottamien epäsuorien tunnekuvausten vähäinen määrä voi kertoa vaikeudesta tunnistaa ja tuottaa tällaista tunnesisältöä, varsinaisia päätelmiä heidän kyvystään tuottaa näitä tunnekuvauksia ei voida tehdä. Tutkittavien tehtävä tutkimuksessa oli vapaasti kertoa näkemästään, eikä heitä pyydetty keskittymään leikkeiden henkilöiden tunnetiloihin tai kertomaan niistä. Tarkempi tunnekuvausten "oikeellisuuden" arviointi mahdollistaisi sen tarkastelun, kuinka hyvin tutkittavien tunnekuvaukset tai tuottamat taustoitukset sopivat videoleikkeisiin. Jatkossa kerrontatutkimukset voisivat arvioida myös tätä aspektia, koska autismikirjon henkilöiden on havaittu tulkitsevan muiden henkilöiden tunteita ja ylipäätänsä sosiaalisia tilanteita eri tavoin kuin neurotyypilliset henkilöt (esim. Eack ym., 2015; Lai ym., 2011; Loukusa, painossa; Loukusa \& Moilanen, 2009; Loukusa ym., 2018; Lönnqvist ym., 2017). Tällainen tarkastelu voi tuoda näkyviin hienojakoisemmat erot pragmaattisessa ymmärtämisessä. Lai ym. (2011) ovat viitanneet aiemmin autismikirjon naisten "pinnallisesti" parempiin sosiaalisen kommunikaation taitoihin, joiden tarkastelussa pragmaattiseen ymmärtämiseen keskittyvä kerrontatutkimus voi olla hyödyllinen ja auttaa lisäämään tietoa siitä, miten autismikirjo tytöillä ja naisilla ilmenee ja miten he eroavat autismikirjon pojista ja miehistä. Näiden sukupuolierojen huomioiminen esimerkiksi kuntoutuksen suunnittelussa olisi tärkeää. Eräs vaikeus tällaisessa tutkimuksessa liittyy kuitenkin siihen, kuinka tunnekuvausten "oikeellisuus" voidaan määritellä, kun tutkittavat tekevät tulkintoja sosiopragmaattisesti monitulkintaisista tilanteista.

Tulostemme mukaan autismikirjon naiset ja autismikirjon miehet siis erosivat epäsuorien tunnekuvausten tuottamisessa. Eroa ei kuitenkaan havaittu suorissa tunnekuvauksissa tai tunnekuvausten taustoittamisen määrässä. Tätä voidaan tulkita sosiaalisen naamioitumisen teorian näkökulmasta siten, että mikäli autismikirjon naiset pyrkivät naamioitumaan, he onnistuivat siinä vain osittain. Aiemmin Boorse ym. (2019) ovat tehneet saman päätelmän tutkiessaan autismikirjon tyttöjen ja poikien kerrontaa. Heidän tutkimuksessaan autismikirjon tyttöjen kerrontatyyli oli sekoitus toisaalta autismikirjon poikien ja toisaalta neurotyypillisten tyttöjen ja neurotyypillisten poikien kerrontaa, mikä kuvaa myös tutkimuksemme autismikirjon naisten kerrontaa. On kuitenkin syytä huomioida tutkimuksemme selkeänä rajoituksena sekä autismikirjon että verrokkiryhmän naisten 
suhteellisen pieni määrä, mikä on voinut vaikuttaa joidenkin ryhmäerojen havaitsematta jäämiseen. Tuloksiamme onkin hyvä kohdella lähinnä viitteitä antavina. Suhteellisen pieni tutkittavien määrä on kuitenkin tyypillinen ongelma sukupuolieroja tarkastelevissa autismikirjon henkilöiden kerrontatutkimuksissa (esim. Conlon ym., 2019; Kauschke ym., 2016). Koska aiempaa tutkimusta sukupuolten välisistä eroista autismikirjon henkilöiden kerronnassa on verrattain vähän ja olemassa oleva tutkimus on keskittynyt pääosin lapsiin, tutkimuksemme tarjoaa rajoitteistaan huolimatta arvokasta tietoa. Lisätutkimusta suuremmilla aineistoilla kuitenkin tarvitaan.

Tämän tutkimuksen aihealueen aiempaa tutkimusta kuvastaa tunnekuvausten määrittelyjen kirjavuus. Osa aiemmista tutkimuksista on esimerkiksi tarkastellut tunnekuvauksia yhdessä mielentilojen kuvausten kanssa tekemättä eroa näiden välille (esim. Fletcher-Watson ym., 2013). Aiemmin muun muassa Siller ym. (2014) ovat huomauttaneet tämän voivan olla ongelmallista, koska he omassa tutkimuksessaan havaitsivat autismikirjon ja neurotyypillisten lasten eroavan toisistaan ainoastaan tuotettujen tunnekuvausten perusteella. Tässä tutkimuksessa emme tarkastelleet lainkaan mielentilojen kuvauksia, vaan keskityimme ainoastaan tunnekuvauksiin, joiden tarkastelua syvensimme jakamalla tunnekuvaukset suoriin ja epäsuoriin kuvauksiin. Tutkimuksemme tulosten mukaan tunnekuvausten tarkastelua onkin hyödyllistä eritellä tarkemmin. Pidämme kiinnostavana, että autismikirjon ja verrokkiryhmän naisten ja miesten välillä ei havaittu eroja suorissa, vaan ainoastaan epäsuorissa tunnekuvauksissa. Aiemmat tutkimukset ovat keskittyneet nimenomaan suoriin tunnekuvauksiin, mikä voikin selittää osaltaan sitä, ettei tunnekuvauksissa useinkaan ole löydetty eroja autismikirjon ja neurotyypillisten henkilöiden välillä. Tutki- muksemme valossa näyttääkin siltä, että tunnesävyttynyttä kerrontaa tuotetaan enemmän kuin varsinaisia suoria tunnekuvauksia, joita esiintyi tutkimuksessamme verrattain vähän kaikilla ryhmillä.

Toinen tärkeä menetelmällinen näkökohta koskee eroja tutkimusasetelmissa tutkimusten välillä. Erityisesti lasten kerrontatutkimuksille on tyypillistä erilaisten kuvakirjojen käyttö kerrontaan kannustamisessa (esim. Capps ym., 2000), kun taas aikuisten kanssa käytetään esimerkiksi valokuvia (esim. Freeth ym., 2011; Fletcher-Watson ym., 2013) ja videoleikkeitä (esim. Barnes ym., 2009). Videoleikkeet voivat muistuttaa enemmän aitoja, nopeasti muuttuvia sosiaalisia tilanteita ja olla siten monimutkaisempia tulkittavia kuin kuvakirjat tai valokuvat. Toisaalta tiedetään, että tunteiden tunnistaminen on neurotyypillisille aikuisille helpompaa videolta kuin staattisesta valokuvasta (Bänziger, Grandjean \& Scherer, 2009). Autismikirjon tutkimuksessa voisi olla jatkossa tärkeää huomioida lisäksi se, että tutkittaville tarjoutuisi mahdollisuus tarkastella myös autismikirjon henkilöiden välistä vuorovaikutusta sen sijaan, että arvioitavana on ainoastaan neurotyypillisten henkilöiden välinen vuorovaikutus (Gernsbacher, Stevenson \& Dern, 2017). Tämän näkökulman huomioiminen tulevaisuudessa voi lisätä tämänhetkistä ymmärrystämme autismikirjon henkilöiden kyvystä tulkita sosiaalisia tilanteita ja esimerkiksi tehdä päätelmiä toisten henkilöiden tunteiden syistä. Lisätutkimusta tarvitaan, jotta voidaan paremmin ymmärtää tällaisten tutkimusasetelmaerojen vaikutusta niin autismikirjon kuin neurotyypillisten henkilöiden tunnekuvausten tuottamiseen ja kerrontaan laajemminkin.

On tarpeen korostaa, että tutkimuksessamme tarkastelimme sukupuolieroja nojautuen biologiseen sukupuoleen. Viimeaikainen tutkimus on kuitenkin osoittanut, että autismikirjon henkilöiden sukupuoli-identiteetti on 
verrattain usein mies-nainen-dikotomian ulkopuolella, erityisesti (biologiselta sukupuoleltaan) naisilla (esim. Dewinter, De Graaf \& Begeer, 2017). Sukupuoli-identiteetin ja sen osana muunsukupuolisuuden huomioiminen voisikin syventää ymmärrystä autismikirjon henkilöiden välisistä eroista. On myös syytä huomioida, että tutkimuksemme autismikirjon henkilöt olivat kognitiiviselta suoriutumiseltaan keskitasoisia eivätkä siten edusta koko laajaa autismikirjoa. Jatkossa tarpeen olisi myös ottaa huomioon aleksitymian mahdollisuus eli henkilön selkeät vaikeudet tunnistaa, tulkita, erotella ja kuvata tunnetiloja. Aleksitymian roolia autismikirjon henkilöiden tunteiden tunnistamisen ja nimeämisen haasteissa onkin pohdittu (Cook, Brewer, Shah \& Bird, 2013). Oletettavasti tällaiset haasteet heijastuisivat myös kerronnassa tuotettuihin tunnekuvauksiin.

Tämän tutkimuksen mukaan näyttää olevan hedelmällistä tarkastella sitä tapaa, jolla tunnekuvauksia tuotetaan. Mielenkiintoista olisi syventää epäsuorien tunnekuvausten tarkastelua, joka oli tässä tutkimuksessa verrattain karkea. Tutkimuksessamme epäsuorat tunnekuvaukset pitivät sisällään monenlaisia tunnekuvauksia (esim. tunnelman kuvauksia ja tunnesävyttynyttä toimintaa), joiden tarkasteleminen erikseen voisi tarkentaa ymmärrystämme autismikirjon naisten ja miesten kerronnan sosiaalisista ulottuvuuksista ja niistä strategioista, joita he käyttävät tunnekuvausten tuottamiseen.

\section{KIITOKSET}

Olemme kiitollisia kaikille tutkittaville tutkimukseen osallistumisesta. Kiitämme myös logopedian opiskelija Anna Lapinojaa aineiston rinnakkaisluokittelusta ja FT Maija Saviniemeä kommenteista tämän käsikirjoituksen aiempaan versioon. Lisäksi kiitämme logopedian opiskelija Linda Lönnqvistiä ja psykologian opiskelija Laura Mämmelää aineiston keräämiseen osallistumisesta sekä dosentti Seppo Laukkaa ja KM Antti Siipoa tutkimuksen teknisen toteutuksen suunnittelusta ja avustamisesta. Kiitämme myös logopedian opiskelija Johanna Karjalaista ja Oulu Autism Research Groupin muita tutkijoita yhteistyöstä. Tutkimuksen rahoittamisesta kiitämme Suomen Akatemiaa, Oulun yliopiston Eudaimonia-instituuttia, Alma \& K. A. Snellmanin säätiötä ja Suomen Aivosäätiötä. Lisäksi haluamme kiittää kahta anonyymiä arvioitsijaa arvokkaista ja huolellisista kommenteista tämän artikkelin aiempiin versioihin. 


\section{LÄHTEET}

American Psychiatric Association. (2013). Diagnostic and statistical manual of mental disorders (5. painos). Arlington, VA: Author.

Avni, I., Meiri, G., Bar-Sinai, A., Reboh, D., Manelis, L., Flusser, H., ... \& Dinstein, I. (2019). Children with autism observe social interactions in an idiosyncratic manner. Autism Research. Julkaistu ennakkoon verkossa. doi:10.1002/ aur.2234

Baixauli, I., Colomer, C., Roselló, B. \& Miranda, A. (2016). Narratives of children with highfunctioning autism spectrum disorder: A metaanalysis. Research in Developmental Disabilities, 59, 234-254.

Bal, E., Harden, E., Lamb, D., Van Hecke, A. V., Denver, J. W. \& Porges, S. W. (2010). Emotion recognition in children with autism spectrum disorders: Relations to eye gaze and autonomic state. Journal of Autism and Developmental Disorders, 40, 358-370.

Barnes, J. L. \& Baron-Cohen, S. (2012). The big picture: Storytelling ability in adults with autism spectrum conditions. Journal of Autism and Developmental Disorders, 42, 1557-1565.

Barnes, J. L., Lombardo, M. V., Wheelwright, S. \& Baron-Cohen, S. (2009). Moral dilemmas film task: A study of spontaneous narratives by individuals with autism spectrum conditions. Autism Research, 2, 148-156.

Baron-Cohen, S. \& Wheelwright, S. (2004). The empathy quotient: An investigation of adults with Asperger syndrome or high functioning autism, and normal sex differences. Journal of Autism and Developmental Disorders, 34, 163-175.

Baron-Cohen, S., Wheelwright, S., Hill, J., Raste, Y. \& Plumb, I. (2001). The "Reading the Mind in the Eyes" Test revised version: A study with normal adults, and adults with Asperger syndrome or high-functioning autism. The Journal of Child Psychology and Psychiatry and Allied Disciplines, 42, 241-251.

Boorse, J., Cola, M., Plate, S., Yankowitz, L., Pandey, J., Schultz, R. T. \& Parish-Morris, J. (2019). Linguistic markers of autism in girls: Evidence of a "blended phenotype" during storytelling. Molecular Autism, 10, 1-12.
Buckner, J. P. \& Fivush, R. (1998). Gender and self in children's autobiographical narratives. Applied Cognitive Psychology, 12, 407-429.

Bänziger, T., Grandjean, D. \& Scherer, K. R. (2009). Emotion recognition from expressions in face, voice, and body: the multimodal emotion recognition test (MERT). Emotion, 9, 691-704.

Capps, L., Losh, M. \& Thurber, C. (2000). "The frog ate the bug and made his mouth sad": Narrative competence in children with autism. Journal of Abnormal Child Psychology, 28, 193-204.

Chevallier, C., Kohls, G., Troiani, V., Brodkin, E. S. \& Schultz, R. T. (2012). The social motivation theory of autism. Trends in Cognitive Sciences, 16, 231-239.

Colle, L., Baron-Cohen, S., Wheelwright, S. \& van der Lely, H. K. (2008). Narrative discourse in adults with high-functioning autism or Asperger syndrome. Journal of Autism and Developmental Disorders, 38, 28-40.

Conlon, O., Volden, J., Smith, I. M., Duku, E., Zwaigenbaum, L., Waddell, C., ... \& Georgiades, S. (2019). Gender differences in pragmatic communication in school-aged children with autism spectrum disorder (ASD). Journal of Autism and Developmental Disorders, 49, 1937-1948.

Cook, R., Brewer, R., Shah, P. \& Bird, G. (2013). Alexithymia, not autism, predicts poor recognition of emotional facial expressions. Psychological Science, 24, 723-732.

Dean, M., Harwood, R. \& Kasari, C. (2017). The art of camouflage: Gender differences in the social behaviors of girls and boys with autism spectrum disorder. Autism, 21, 678-689.

Dewinter, J., De Graaf, H. \& Begeer, S. (2017). Sexual orientation, gender identity, and romantic relationships in adolescents and adults with autism spectrum disorder. Journal of Autism and Developmental Disorders, 47, 2927-2934.

Eack, S. M., Mazefsky, C. A. \& Minshew, N. J. (2015). Misinterpretation of facial expressions of emotion in verbal adults with autism spectrum disorder. Autism, 19, 308-315. 
Fletcher-Watson, S., Leekam, S. R. \& Findlay, J. M. (2013). Social interest in high-functioning adults with autism spectrum disorders. Focus on Autism and Other Developmental Disabilities, 28, 222-229.

Freeth, M., Ropar, D., Mitchell, P., Chapman, P. \& Loher, S. (2011). Brief report: How adolescents with ASD process social information in complex scenes. Combining evidence from eye movements and verbal descriptions. Journal of Autism and Developmental Disorders, 41, 364-371.

Gernsbacher, M. A., Stevenson, J. L. \& Dern, S. (2017). Specificity, contexts, and reference groups matter when assessing autistic traits. PLoS One, 12, e0171931.

Jansson-Verkasalo, E., Kujala, T., Jussila, K., Mattila, M. L., Moilanen, I., Näätänen, R.,... \& Korpilahti, P. (2005). Similarities in the phenotype of the auditory neural substrate in children with Asperger syndrome and their parents. European Journal of Neuroscience, 22, 986-990.

Kauschke, C., van der Beek, B. \& Kamp-Becker, I. (2016). Narratives of girls and boys with autism spectrum disorders: Gender differences in narrative competence and internal state language. Journal of Autism and Developmental Disorders, 46, 840-852.

Klin, A. (2000). Attributing social meaning to ambiguous visual stimuli in higher-functioning autism and Asperger syndrome: The social attribution task. The Journal of Child Psychology and Psychiatry and Allied Disciplines, 41, 831846.

Koo, T. K. \& Li, M. Y. (2016). A guideline of selecting and reporting intraclass correlation coefficients for reliability research. Journal of Chiropractic Medicine, 15, 155-163.

Kuusikko, S., Haapsamo, H., Jansson-Verkasalo, E., Hurtig, T., Mattila, M. L., Ebeling, H.,... \& Moilanen, I. (2009). Emotion recognition in children and adolescents with autism spectrum disorders. Journal of Autism and Developmental Disorders, 39, 938-945.
Kuusikko, S., Pollock-Wurman, R., Jussila, K., Carter, A. S., Mattila, M. L., Ebeling, H.,... Moilanen, I. (2008). Social anxiety in highfunctioning children and adolescents with autism and Asperger syndrome. Journal of Autism and Developmental Disorders, 38, 1697-1709.

Lai, M. C., Lombardo, M. V., Auyeung, B., Chakrabarti, B. \& Baron-Cohen, S. (2015). Sex/gender differences and autism: Setting the scene for future research. Journal of the American Academy of Child \& Adolescent Psychiatry, 54, $11-24$.

Lai, M. C., Lombardo, M. V., Pasco, G., Ruigrok, A. N., Wheelwright, S. J., Sadek, S. A., ... \& MRC AIMS Consortium. (2011). A behavioral comparison of male and female adults with high functioning autism spectrum conditions. PLoS One, 6: e20835.

Lord, C., Rutter, M., DiLavore, P. C. \& Risi, S. (2000). Autism diagnostic observation schedule (ADOS). Los Angeles: Western Psychological Services.

Lord, C., Rutter, M. \& Le Couteur, A. (1995). Autism diagnostic interview - Revised (ADI-R) (3rd ed.). Los Angeles: Western Psychological Services.

Losh, M. \& Gordon, P. C. (2014). Quantifying narrative ability in autism spectrum disorder: A computational linguistic analysis of narrative coherence.Journal of Autism and Developmental Disorders, 44, 3016-3025.

Loukusa, S. (painossa). Autism spectrum disorder. Teoksessa L. Cummings (toim.), Pragmatic Language Disorders: Complex and Underserved Populations. Springer.

Loukusa, S. \& Moilanen, I. (2009). Pragmatic inference abilities in individuals with Asperger syndrome or high-functioning autism. A review. Research in Autism Spectrum Disorders, 3, 890904.

Loukusa, S., Mäkinen, L., Kuusikko-Gauffin, S., Ebeling, H. \& Leinonen, E. (2018). Assessing social-pragmatic inferencing skills in children with autism spectrum disorder. Journal of Communication Disorders, 73, 91-105. 
Lönnqvist, L., Loukusa, S., Hurtig, T., Mäkinen, L., Siipo, A., Väyrynen, E., ... \& Ebeling, H. (2017). How young adults with autism spectrum disorder watch and interpret pragmatically complex scenes. The Quarterly Journal of Experimental Psychology, 70, 2331-2346.

Mattila, M.-L., Kielinen, M., Jussila, K., Linna, S.-L., Bloigu, R., Ebeling, H. \& Moilanen, I. (2007). An epidemiological and diagnostic study of Asperger syndrome according to four sets of diagnostic criteria. Journal of the American Academy of Child and Adolescent Psychiatry, 46, 636-646.

Morrison, K. E., DeBrabander, K. M., Jones, D. J., Faso, D. J., Ackerman, R. A. \& Sasson, N. J. (2019). Outcomes of real-world social interaction for autistic adults paired with autistic compared to typically developing partners. Autism. Julkaistu ennakkoon verkossa. doi: 10.1177/1362361319892701.

Mäkinen, L., Loukusa, S., Leinonen, E., Moilanen, I., Ebeling, H. \& Kunnari, S. (2014). Characteristics of narrative language in autism spectrum disorder: Evidence from the Finnish. Research in Autism Spectrum Disorders, 8, 987996.

Niedźwieńska, A. (2003). Gender differences in vivid memories. Sex Roles, 49, 321-331.

Norbury, C. F., Gemmell, T. \& Paul, R. (2014). Pragmatics abilities in narrative production: A cross-disorder comparison. Journal of Child Language, 41, 485-510.

Parish-Morris, J., Liberman, M. Y., Cieri, C., Herrington, J. D., Yerys, B. E., Bateman, L., ... \& Schultz, R. T. (2017). Linguistic camouflage in girls with autism spectrum disorder. Molecular Autism, 8, 48.

Schulkind, M., Schoppel, K. \& Scheiderer, E. (2012). Gender differences in autobiographical narratives: He shoots and scores; she evaluates and interprets. Memory \& Cognition, 40, 958965.

Siller, M., Swanson, M. R., Serlin, G. \& Teachworth, A. G. (2014). Internal state language in the storybook narratives of children with and without autism spectrum disorder: Investigating relations to theory of mind abilities. Research in Autism Spectrum Disorders, 8,589-596.
Tomczak, M. \& Tomczak, E. (2014). The need to report effect size estimates revisited. An overview of some recommended measures of effect size. Trends in Sport Sciences, 1, 19-25.

Tracy, J. L., Robins, R. W., Schriber, R. A. \& Solomon, M. (2011). Is emotion recognition impaired in individuals with autism spectrum disorders? Journal of Autism and Developmental Disorders, 41, 102-109.

Volden, J., Magill-Evans, J., Goulden, K. \& Clarke, M. (2007). Varying language register according to listener needs in speakers with autism spectrum disorder. Journal of Autism and Developmental Disorders, 37, 1139-1154.

Wechsler, D. (2012). WAIS-IV - Wechsler Adult Intelligence Scale - IV. Helsinki: Psykologien Kustannus Oy.

Weiss, L. A., Arking, D. E., \& the Gene Discovery Project of John Hopkins \& the Autism Consortium. (2009). A genome-wide linkage and association scan reveals novel loci for autism. Nature, 461, 802-808.

World Health Organization. (1993). International classification of mental and behavioural disorders (ICD-10). Diagnostic criteria for research. Geneva: Author.

World Health Organization. (2018). International classification of diseases (ICD-11). Haettu 27.2.2020 osoitteesta https://www.who.int/ classifications/icd/en/ 


\section{SEX DIFFERENCES IN REFERENCES TO EMOTIONS IN THE NARRATIVES OF YOUNG ADULTS ON THE AUTISM SPECTRUM AND CONTROLS}

Katja Dindar, Research Unit of Logopedics, University of Oulu

Soile Loukusa, Research Unit of Logopedics, University of Oulu

Leena Mäkinen, Research Unit of Logopedics, University of Oulu

Aija Kotila, Research Unit of Logopedics, University of Oulu

Tuula Hurtig, Research Unit of Clinical Neuroscience, PEDEGO Research Unit,

University of Oulu and Clinic of Child Psychiatry, Oulu University Hospital

Hanna Ebeling, Clinic of Child Psychiatry, Oulu University Hospital and

PEDEGO Research Unit, University of Oulu

Previous studies have reported mixed findings about how females and males on the autism spectrum orient to social situations, interpret and tell narratives about them. This study examined how females $(n=7)$ and males $(n=24)$ on the autism spectrum and control females $(n=11)$ and males $(n=24)$ refer to the emotions of characters seen in socio-pragmatically complex videos. We investigated the amount of explicit and implicit references to emotions in the participants' narratives and whether their references included contextual information. Results showed that both control females and females on the autism spectrum made more implicit references to emotions than males on the autism spectrum. Males, but not females, on the autism spectrum also provided less contextual information than control females and control males. There were no observed differences between control females and control males. These findings encourage paying attention to sex differences in order to better identify females and males on the autism spectrum and to provide them with more targeted support.

Keywords: autism spectrum, emotion, narrative, reference, sex 